\title{
Analiza obrazu płomienia w celu wykorzystania komputerowych systemów wizyjnych do oceny i nadzorowania procesu spalania
}

\begin{abstract}
W artykule przedstawiono podsumowanie dotychczas prowadzonych badań nad analizą płomienia jako zjawiska. Skomentowano napotkane problemy. Zaprezentowano ogólne wytyczne i kierunki kontynuacji badań nad płomieniem jako obrazem rejestrowanym przez urządzenia techniczne, które będą kontynuowane przez autora w celu wykonania wizyjnego systemu diagnostycznego do analizy procesu spalania.
\end{abstract}

Słowa kluczowe: jakość spalania, spalanie, płomień, rozpoznawanie obrazów.

\section{Image flame analysis in order to make use of computer vision systems to evaluate and supervise the combustion process}

The article presents a summary of research conducted so far, on the analysis of the flame as a phenomenon. Problems encountered were commented on. It provides general guidelines and directions for continued research on the flame, as the image recorded by technical devices, which will be continued by the author in order to perform a vision diagnostic system for the analysis of the combustion process.

Key words: the combustion quality, combustion, image recognition.

\section{Wstęp}

Rozważania zawarte w artykule mają przybliżyć autora do właściwego pod względem zastosowania w komputerowym systemie wizyjnym opisu procesu spalania, a przede wszystkim opisu obrazu płomienia - jego właściwości i za- leżności pomiędzy rejestrowanym obrazem procesu spalania a jakością tego procesu. Opisane badania prowadzone są przez autora $\mathrm{w}$ celu zastosowania wizyjnych systemów diagnostycznych do analizy procesu spalania.

\section{Czym jest płomień}

Mimo że intuicyjnie każdy człowiek wie, czym jest płomień, nie istnieje ścisła jego definicja. W [7] autor, podsumowując pięćdziesiąt lat badań nad płomieniem, definiuje płomień jako zjawisko, które zawsze może być określone niejako po fakcie wystąpienia, ale wydaje się, że definicja ogólna, z warunkiem koniecznym i wystarczającym, nie istnieje. W literaturze można znaleźć wiele definicji pojęcia „płomień” kładących nacisk na te aspekty zjawiska, które są analizowane lub kluczowe z punktu widzenia dziedziny, w której definicja funkcjonuje $[4,7,15,21]$. Wnioski płynące z przytoczonych publikacji potwierdzają prace innych badaczy, w których w zależności od przyjętych założeń (rodzajów palników, spalanych gazów itp.) i opisywanych procesów technologicznych zastosowanie mają różne modele matematyczne procesu spalania, a co za tym idzie - płomienia jako zjawiska [np. 6, 11, 12].

Biorąc pod uwagę cel prowadzonych badań, przez proces spalania w niniejszej pracy rozumie się zbiór reakcji fi- 
zycznych i chemicznych wzajemnie na siebie oddziałujących i nawzajem się warunkujących. Reakcje chemiczne są egzotermiczne i zachodzą gwałtownie, między paliwem a tlenem, w ściśle określonych warunkach przez występujące zjawiska fizyczne. Aby mówić o zjawisku spalania, reakcja utleniania musi być gwałtowna i egzotermiczna oraz przebiegać w tlenie, ponieważ:

- niezachodząca gwałtownie reakcja utleniania odbywa się bez widocznego przyrostu temperatury wokół produktów reakcji,

- istnieją endotermiczne reakcje utleniania, np. reakcja utleniania azotu, w której wyniku powstaje tlenku azotu(II),

- inne reakcje utleniania, nie tylko z udziałem tlenu, prowadzą do wypromieniowania energii w postaci fal elektromagnetycznych, również w zakresie promieniowania widzialnego.

Jak wszystkie ciała także produkty reakcji chemicznych, uwzględniając również ich widma emisyjne, promieniują w pełnym zakresie fal elektromagnetycznych [18]. Powoduje to, że efekty towarzyszące procesowi spalania można obserwować w różnych zakresach fal elektromagnetycznych, np. podczerwieni, światła widzialnego, ultrafioletu. W różnych zakresach fal elektromagnetycznych wyglądają one inaczej (fotografia 1). Zdarza się, że efekty wizualne są słabo widoczne lub niewidoczne w świetle widzialnym, np. spalanie wodoru. Ogólnie im wyższa temperatura spalania, tym efekt zachodzących reakcji lepiej widoczny w zakresie fal elektromagnetycznych bliższych ultrafioletowi, analogicznie im temperatura niższa, tym efekt wyraźniejszy w podczerwieni (rysunek 1).
Na fotografii 1 przedstawiono zarejestrowane w różnych zakresach promieniowania elektromagnetycznego obrazy procesu spalania gazu wysokometanowego (G-20) na palniku Bunsena [2, 3]. Obrazy odnoszą się do jednego ustawienia palnika. Obraz płomienia zarejestrowany w świetle widzialnym różni się od obrazów zarejestrowanych w innych zakresach promieniowania elektromagnetycznego.

Uwzględniając powyższe sformułowania na potrzeby dalszych prac związanych z systemami rozpoznawania obrazów, płomień zdefiniowano jako zjawisko wypromieniowania energii w postaci fal elektromagnetycznych w dowolnym ich zakresie w efekcie gwałtownej egzotermicznej reakcji utleniania paliwa podczas procesu spalania z udziałem tlenu.

Reprezentantem płomienia może być zarejestrowany przez urządzenie techniczne obraz wypromieniowanych fal elektromagnetycznych $\mathrm{w}$ dowolnych zakresach promieniowania.

Takie przyjęcie definicji obrazu płomienia nie ogranicza go do efektów zjawiska zachodzących wyłącznie w zakresie światła widzialnego, otwierając drogę do eksperymentów z wykorzystaniem rejestratorów obrazu działających w różnych zakresach promieniowania.

Rozważania te prowadzone są w celu wykonania modelu płomienia $\mathrm{w}$ rozumieniu podanych wyżej definicji. To z kolei

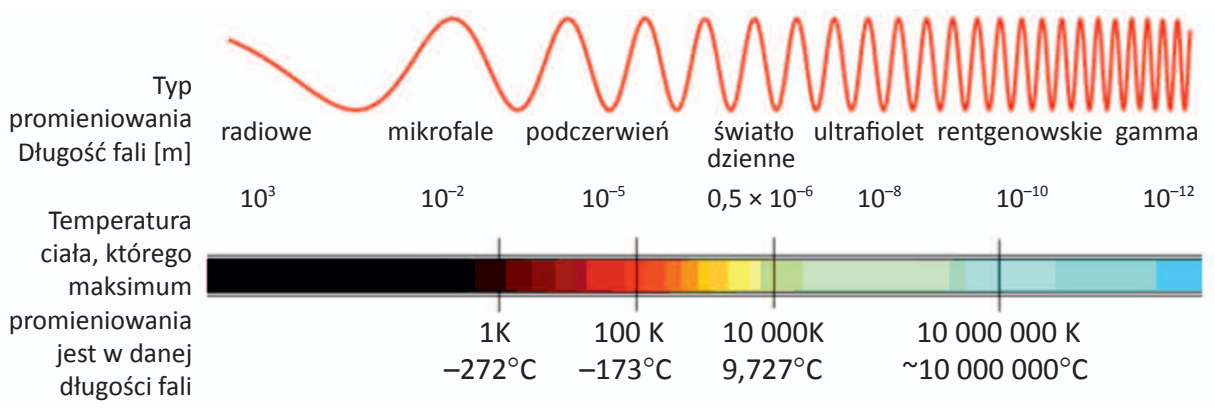

Rys. 1. Widmo fal elektromagnetycznych i odpowiadające mu temperatury ciała promieniującego fale $\mathrm{z}$ maksymalną energią

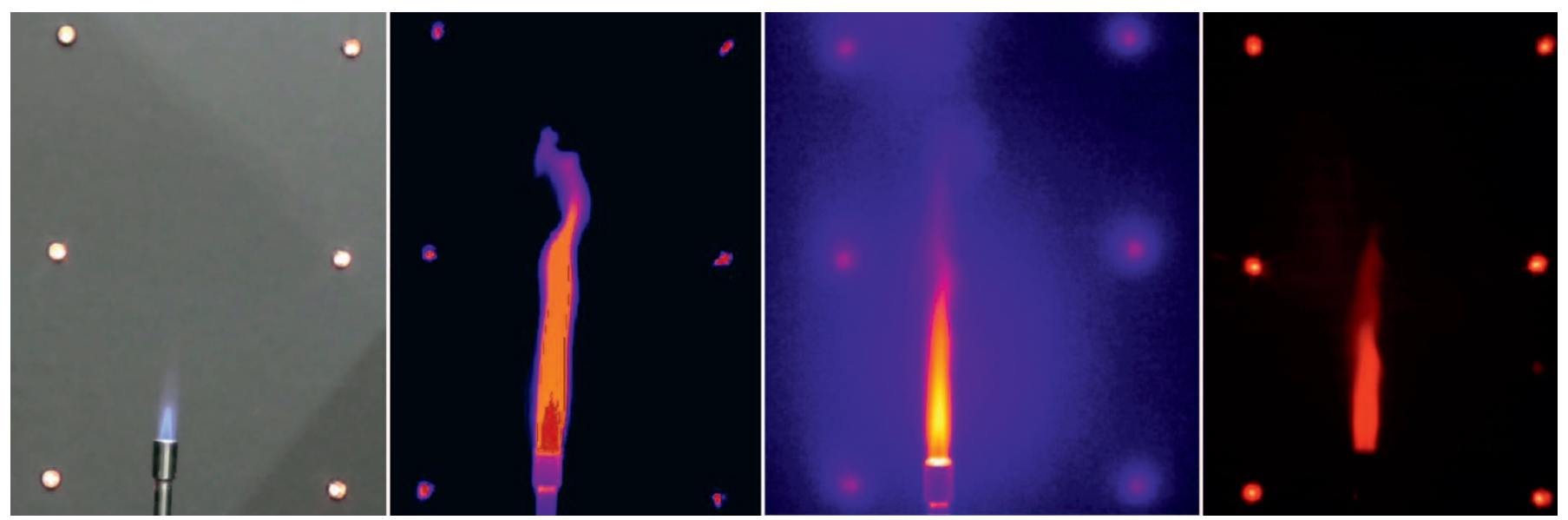

Fot. 1. Obraz płomienia w różnych zakresach fal elektromagnetycznych. Od lewej: promieniowanie widzialne, promieniowanie

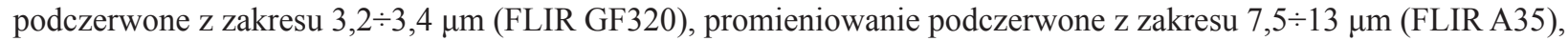
promieniowanie podczerwone z zakresu $0,9 \div 1,7 \mu \mathrm{m}$ (NIT NATIVE WDR ${ }^{\mathrm{TM}}$ ) 
pozwoli na przygotowanie modelu procesu spalania umożliwiającego wykorzystanie komputerowych systemów rozpoznawania i klasyfikacji obrazów do nadzorowania i prowadzenia procesu.

Dobre poznanie omawianego zjawiska pozwoli podjąć próby zautomatyzowania procesów, które z racji swej natury są niedostępne dla klasycznej automatyki. Dotyczy to głównie procesów, w których mogą zachodzić subtelne zmiany warunków podczas ich trwania i których poprawny przebieg zależy głównie od wiedzy i doświadczenia ich operatora. Przykładem takiego procesu jest spawanie gazowe za pomocą palnika acetylenowo-tlenowego. O próbie zautomatyzowania procesu spawania i lutowania gazowego można przeczytać w artykule [9]. Zespół autorów podaje wymagania, jakie powinni spełniać spawacze i lutowacze gazowi, oraz podejmuje próbę opisu procesu spawania i lutowania gazowego w sposób umożliwiający zaimplementowanie wiedzy eksperckiej z tego zakresu do systemu komputerowego w celu wykorzystania metod rozpoznawania obrazów do sterowania ruchami robota spawalniczego. Tego rodzaju proces wymaga ciągłej kontroli płomienia palnika w zależności od postępującego topnienia metalu, procesu przeważnie niepowtarzalnego, co uniemożliwia jego klasyczną automatyzację. Proces ten, ze względu na czas spawania/lutowania oraz osiągane temperatury, wymaga stałego nadzoru systemu pozwalającego na regulację urządzeń wykonawczych przy subtelnych zmianach struktury, kształtu lub innych cech obrabianych obiektów.

Wielu badaczy zajmuje się analizą wpływu poszczególnych czynników na proces spalania, wygląd i parametry płomienia. Tak na przykład w [22-25] można znaleźć badania na temat wpływu paliwa gazowego na jakość procesu spalania. W pracy [8] dyskutowany jest wpływ składu paliwa na parametry płomienia gazowego (emisyjność - zdolność wypromieniowania energii w postaci fali elektromagnetycznej). Inne podejście prezentują autorzy prac [16, 17, 19], w których zwracając uwagę na bezpieczeństwo użytkowania konkretnych urządzeń, przedstawiają badania nad wpływem parametrów otaczającego środowiska na jakość działania urządzeń (tu: gazowych urządzeń grzewczych z otwartą komorą spalania $[16,17])$ i prezentują symulacje komputerowe warunków, które mają wpływ na jakość działania urządzeń gazowych [19]. Jeszcze inne podejście do modelowania i analizy procesu spalania można znaleźć w pracach $[5,14]$.

W artykule [3] opisano badania płomienia gazowego zmierzające do skonstruowania modelowego zestawu jego cech umożliwiających automatyczny nadzór i analizę procesu spalania.

Podczas prowadzenia badań opisanych w [2] i [3], uwzględniając wnioski z prac cytowanych powyżej, prezentujących badania pracowników Zakładu Użytkowania Paliw Instytutu Nafty i Gazu - Państwowego Instytutu Badawczego, zidentyfikowano przykładowe zmienne wpływające w różnym stopniu na obrazy płomienia (oczywiście to tylko ułamek z całego zbioru parametrów, które mogą wpływać na płomień):

- rodzaj spalanego paliwa (paliwa gazowe, ciekłe lub stałe),

- chemiczny skład paliwa,

- warunki zasilania konkretnego palnika,

- temperatura powietrza,

- ciśnienie atmosferyczne,

- wymiana powietrza w komorze spalania,

- prędkość napływu powietrza do komory spalania (dynamika przepływu powietrza do spalania),

- stopień nagrzania komory,

- ruch powietrza w obrębie płomienia - zarówno szybkość, jak i kierunek,

- ruch masy powietrza w strefie płomienia - powietrze poruszające się w różnych strefach płomienia wpływa w różny sposób na jego obraz,

- konstrukcja komory spalania - kształt komory, jej wielkość w stosunku do płomienia.

Parametry te wpływają na jakość spalania w różny sposób, w zależności od konkretnego przypadku.

Zjawisko wydawać się może zupełnie przypadkowe, wręcz chaotyczne ${ }^{1}$. W związku z tym rozpoczęto poszukiwanie teorii, która mogłaby przybliżyć $i$ wytłumaczyć choć w minimalnym stopniu charakter płomienia. W celu budowy systemu wizyjnego i implementacji wiedzy eksperckiej w systemie komputerowym konieczne jest poznanie modelu zjawiska opisującego jego zachowanie.

Po przeprowadzeniu eksperymentów opisanych w $[2,3]$ rozpoczęto poszukiwania odpowiedzi na pytanie, jaki charakter ma zjawisko płomienia, jego obrazu (czyli wypromieniowanej energii podczas spalania), mogącego być zbiorem danych wejściowych dla systemu wizyjnego. Mnogość zmiennych, liczba zachodzacych reakcji chemicznych i zjawisk fizycznych podczas analizowanego zjawiska powodują, że podanie ogólnego wzoru umożliwiającego wyliczenie obrazu płomienia i dynamiki jego zmienności, a co za tym idzie - chwilowych zawartości produktów spalania w otoczeniu analizowanego płomienia, jest bardzo skomplikowane.

$\mathrm{Z}$ drugiej strony istnieje pewna stabilność zjawiska, wszak możliwe jest określenie wskaźników jakości spalania w urządzeniach, co czyni się z powodzeniem od wielu lat. Wskaźniki jakości są również powtarzalne i odtwarzalne. Wszystkie prowadzone badania certyfikacyjne bazują na tym fakcie.

${ }^{1} \mathrm{Tu}$ w znaczeniu potocznym, w dalszej części artykułu wyrażenia „chaos”, „zjawisko chaotyczne” rozumiane są jako element teorii chaosu deterministycznego. 
Poszukiwania odpowiedzi zaprowadziły autora na grunt teorii chaosu deterministycznego $[10,20]$.

Chaos można zdefiniować jako nieprzewidywalne długookresowe zachowanie wynikające z wrażliwości na warunki początkowe. Nie jest to jednak warunek wystarczający, aby stwierdzić chaotyczność zjawiska. Chaos deterministyczny powstaje w deterministycznych układach nieliniowych. Do stwierdzenia chaotyczności zjawiska wymaga się odpowiedniego zachowania trajektorii będących reprezentacją rozwiązań równań opisujących zjawisko w przestrzeni fazowej.

\section{Czy płomień jest zjawiskiem chaotycznym?}

Jako że jednoznaczna odpowiedź wymaga dalszych badań i dokładniejszego poznania przez autora zarówno zjawiska płomienia, jak i teorii chaosu deterministycznego, poniższe stwierdzenia są wyłącznie hipotezą.

Pierwszym napotkanym problemem stają się równania opisujące płomień, a ściślej mówiąc - jego obraz, jako zjawisko zdefiniowane w artykule.

\section{Jak wybrać parametry i stopień szczegółowości opisu?}

Ponieważ brak w przyjętej definicji ograniczenia co do spektrum fal, model powinien zawierać równania opisujące energię wypromieniowywaną w czasie zależną od długości fali elektromagnetycznej i udziału poszczególnych reagentów. Prawdopodobnie takie równanie pozwoliłoby opisać płomień w stopniu wystarczającym do jego analizy. Równanie musiałoby prawidłowo opisywać następujące zachowania płomienia, w zależności od współczynników:

- płomień kinetyczny - stabilny płomień niewrażliwy na zmiany warunków początkowych, np. płomień spawalniczych palników acetylenowo-tlenowych przy odpowiednim ustawieniu,

- płomień kinetyczno-dyfuzyjny - stabilny płomień z widoczną częścią dyfuzyjną, której zachowanie jest okresowe,

- płomień typowo dyfuzyjny, który jest wrażliwy na każdą najmniejszą zmianę warunków początkowych, np. spalanie paliw stałych.
Ostatni zbiór rozwiązań (płomień typowo dyfuzyjny) może ujawnić istnienie chaosu deterministycznego w zjawisku, a rozwiązania mogą okazać się quasi-okresowe.

Oczywiście tylko wnikliwa analiza zjawiska i opisujących go równań może wykazać prawdziwość postawionej hipotezy. Po przeprowadzonej analizie może się również okazać, że płomień dyfuzyjny jest zjawiskiem losowym i nie da się stosować teorii chaosu deterministycznego do jego opisu.

Istnieją jednak przesłanki ku temu, aby sądzić, że płomień jest zjawiskiem chaotycznym.

- Jak podano w [20] i [10], jednym z pól, na których teoria chaosu święci największe sukcesy, jest hydrodynamika, a drugim - termodynamika. Teorię chaosu deterministycznego stosuje się do opisu turbulentnego przepływu płynów oraz do opisu przypadków przepływu ciepła (np. [1]). W związku z tym można się spodziewać, że opis ten będzie również adekwatny do spalania dyfuzyjnego. Na płomień jako zjawisko niebanalny wpływ ma sposób przepływu paliwa i utleniacza, który podczas spalania dyfuzyjnego może być turbulentny, a także przekazywanie ciepła w płomieniu.

- Płomień dyfuzyjny - obraz procesu spalania - wydaje się quasi-okresowy, co umożliwia badania średnich wskaźników jakości spalania w przedziałach czasu i gwarantuje powtarzalność wyników, np. badania certyfikacyjne urządzeń spalających paliwa stałe.

- Opublikowano pracę [13], w której autorzy z powodzeniem wykorzystują teorię chaosu deterministycznego do modelowania zjawiska zachodzącego w płomieniu dyfuzyjnym.

Postawiona hipoteza o istnieniu chaosu deterministycznego w zachowaniu płomienia otwiera szerokie pole do badań nad jego możliwymi modelami. Autor ma nadzieję, że ich kontynuacja w kolejnych latach pozwoli lepiej poznać omawiane zjawisko, umożliwiając zastosowanie nowych metod sterowania procesem spalania, w tym komputerowych systemów eksperckich i systemów rozpoznawania obrazów.

Prosimy cytować jako: Nafta-Gaz 2016, nr 12, s. 1119-1123, DOI: 10.18668/NG.2016.12.16

Artykuł nadesłano do Redakcji 7.10.2016 r. Zatwierdzono do druku 13.12.2016 r.

Artykuł powstał na podstawie pracy statutowej pt. Metody rozpoznawania obrazów w procesie oceny jakości spalania paliw gazowych. Czesść druga - analiza jakości palenia palników gazowych - praca INiG - PIB na zlecenie MNiSW; nr zlecenia: 51/ GU/15/01, nr archiwalny: DK-4100-51/15.

\section{Literatura}

[1] Angeli D., Pagano A., Corticelli M.A., Barozzi G.S.: Routes to chaos in confined thermal convection arising from a cylindrical heat source. CMSIM Journal 2011, no. 1, s. 61-68.

[2] Basiura M.: Metody rozpoznawania obrazów w procesie oce- ny jakości spalania paliw gazowych. Identyfikacja cech obrazu płomienia w paśmie podczerwonym. Praca INiG - PIB na zlecenie MNiSW; nr zlecenia: 14/GU/2014, nr archiwalny: DK-4100-14/14. 
[3] Basiura M.: Próba wykorzystania metod rozpoznawania obrazów do oceny jakości spalania gazu. Nafta-Gaz 2015, nr 5, s. 314-319.

[4] Bełtowska-Brzezińska M.: Podstawy termodynamiki chemicznej. Skrypt do wykładów. Wydział Chemii UAM, Poznań 2009.

[5] Bialik W., Gil S., Mocek P.: Predykcja CFD procesów emisji zanieczyszczeń gazowych w wysokotemperaturowych komorach spalania. Czasopismo Techniczne. Środowisko 2009, zeszyt 3-Ś, s. 3-12.

[6] Bilger R.W.: Future progress in turbulent combustion research. Progress in Energy and Combustion Science 2000, vol. 26, issues 4-6, s. 367-380.

[7] Essenhigh R.H.: What is a flame? A review of 50 years of research. Combustion Chemistry of Traditional and NonTraditional Fuels, 1998 Spring, DALLAS, Prepr. Am. Chem. Soc., Div. Pet. Chem. 1998, vol. 43, no. 1, s. 100-106.

[8] Gebhardt Z.: Wplyw parametrów substratów na wyplywie z palnika typu rura $w$ rurze na emisyjność dyfuzyjnych płomieni gazu ziemnego. Praca doktorska, Gliwice 1983.

[9] Jastrzębski R., Cyganek B., Przytula J., Jastrzębska I., Szczyrbak K.: Teoria wyszkolenia fizycznego spawaczy i lutowaczy gazowych kluczem do kopiowania ruchów spawacza na ruchy robota. Dozór Techniczny 2014, lipiec-październik nr 4-5, s. 74-82.

[10] Lachowicz M.: Matematyka chaosu. Matematyka-Społeczeństwo-Nauczanie 1999, nr 22, s. 21-28.

[11] Lipatnikov A.N., Chomiak J.: Turbulent flame speed and thickness: phenomenology, evaluation, and application in multi-dimensional simulations. Progress in Energy and Combustion Science 2002, vol. 28, no. 1, s. 1-74.

[12] Moreau V.: A self-similar premixed turbulent flame model. Applied Mathematical Modelling 2009, vol. 33, no. 2, s. 835-851.

[13] Mukerji S., McDonough J.M., Menguc M.P., Manickavasagam S., Chung S.: Chaotic map models of soot fluctuations in turbulent diffusion flames. International Journal of Heat and Mass Transfer 1998, vol. 41, no. 24, s. 4095-4112.

[14] Nimon J.: Could Burning Fuel on the Space Station Ultimately Save Fuel on Earth? International Space Station Program Science Office, NASA's Johnson Space Center; http:// www.nasa.gov/mission_pages/station/research/news/slice. html (dostęp: sierpień 2015).

[15] Pudlik W.: Termodynamika. Podręcznik przeznaczony dla studiujacych na kierunkach: Mechanika i Energetyka. Politechnika Gdańska 2011.
[16] Rataj M.: Bezpieczeństwo użytkowania gazowych urządzeń grzewczych z otwarta komora spalania. Nafta-Gaz 2013, nr 6, s. $455-462$.

[17] Rataj M.: Ocena wptywu ciagu wstecznego na działanie palnika inżektorowego. Nafta-Gaz 2015, nr 5, s. 320-326.

[18] Sala A.: Radiacyjna wymiana ciepła. Warszawa, Wydawnictwa Naukowo-Techniczne, 1982.

[19] Siuda T.: Numeryczne modelowanie odwróconego ciagu w budynku mieszkalnym za pomoca pakietu CFD FLUENT. Gaz, Woda i Technika Sanitarna 2013, nr 12, s. 470-474.

[20] Stewart I.: Czy Bóg gra w kości? Nowa matematyka chaosu. Warszawa, PWN, 2001.

[21] Sural Z. (red.): Szkolenie strażaków ratowników OSP. Część I. Józefów, CNBOP, 2009.

[22] Wojtowicz R.: Dywersyfikacja dostaw gazu do Polski a wymienność paliw - wymagania prawne odnośnie jakości gazów rozprowadzanych w kraju oraz możliwe kierunki dywersyfikacji. Wiadomości Naftowe i Gazownicze 2011, nr 1, s. 4-7.

[23] Wojtowicz R.: Ocena gazu granicznego G21 pod katem jego przydatności do określania jakości spalania gazów ziemnych wysokometanowych pochodzacych z regazyfikacji $L N G$ w urzadzeniach użytku domowego. Nafta-Gaz 2013, nr 8, s. 599-612.

[24] Wojtowicz R.: Wplyw składników gazu ziemnego wysokometanowego (etanu i propanu) na jakość spalania w kotłach gazowych i gazowych przeptywowych ogrzewaczach wodyanaliza porównawcza teoretycznych metod oceny wymienności z wynikami pomiarów. Praca INiG na zlecenie MNiSW; nr zlecenia: 34/GU/2011, nr archiwalny: DK-4100-34/11.

[25] Wojtowicz R.: Zagadnienia wymienności paliw gazowych, wymagania prawne odnośnie jakości gazów rozprowadzanych w Polsce oraz możliwe kierunki dywersyfikacji. Nafta-Gaz 2012, nr 6, s. 359-367.

Mgr inż. Maciej BASIURA

Asystent w Laboratorium Badań Urządzeń Gazowych i Grzewczych w Zakładzie Użytkowania Paliw.

Instytut Nafty i Gazu - Państwowy Instytut Badawczy

ul. Lubicz 25 A

31-503 Kraków

E-mail: maciej.basiura@inig.pl 